\begin{tabular}{|} 
Ambiente \& Água - An Interdisciplinary Journal of Applied Science \\
ISSN 1980-993X - doi:10.4136/1980-993X \\
www.ambi-agua.net \\
E-mail: ambi.agua@gmail.com
\end{tabular}

\title{
High iron content in river waters: environmental risks for aquatic biota and human health
}

\author{
ARTICLES doi:10.4136/ambi-agua.2751
}

Received: 15 May 2021; Accepted: 19 Jul. 2021

\author{
Lucilene Finoto Viana1 ${ }^{1}$; Bruno do Amaral Crispim ${ }^{1}$; \\ Juliana Caroline Vivian Sposito ${ }^{1}$; ;ilena Perez de Melo ${ }^{1}$; \\ Luiza Flávia Veiga Francisco1 ${ }^{1 D}$; Valter Aragão do Nascimento ${ }^{2}$; \\ Alexeia Barufatti ${ }^{*}$ (iD)
}

\begin{abstract}
${ }^{\mathbf{1}}$ Faculdade de Ciências Biológicas e Ambientais. Universidade Federal da Grande Dourados (UFGD), Cidade Universitária, Rodovia Dourados Itahum, Km 12, Caixa Postal 364, CEP: 79804-970, Dourados, MS, Brazil.

E-mail: lucilenefinoto@hotmail.com, brunocrispim.bio@gmail.com,juliana_sposito@ hotmail.com, milenabio16@gmail.com, luizaveiga10@hotmail.com

${ }^{2}$ Faculdade de Medicina. Universidade Federal de Mato Grosso do Sul (UFMS), Cidade Universitária, Caixa Postal 549, CEP: 79070-900, Campo Grande, MS, Brazil. E-mail: aragao60@ hotmail.com

*Corresponding author. E-mail: alexeiabarufatti@ufgd.edu.br
\end{abstract}

\begin{abstract}
This study assessed the concentrations of metals in the Dourados and Brilhante Rivers, investigated the influence of landscape features surrounding these rivers on water quality, and evaluated the risks associated with metal contamination for aquatic biota and human health. Sampling was conducted at eighteen sites distributed along the rivers in June 2016. The concentrations of metals $(\mathrm{Cu}, \mathrm{Zn}, \mathrm{Mn}, \mathrm{Fe}, \mathrm{Cr}, \mathrm{Al}$ and $\mathrm{Co})$ in the water were analyzed by inductively coupled plasma optical emission spectroscopy. All the samples possessed Fe concentrations above the threshold value for aquatic biota $\left(0.3 \mathrm{mg} \mathrm{L}^{-1}\right)$. Moreover, land use and land cover assessment of the study area revealed extensive agriculture activity, particularly in areas surrounding the Dourados River headwaters. Fe bioavailability for both rivers indicated risks for aquatic biota and human health. Overall, the elevated Fe content in these rivers was attributed to anthropogenic activity in the vicinity of these water bodies and the soil characteristics of the area. Considering the importance of river basins, it is necessary to implement public policies for their conservation, especially those related to the cultivation of forests of native species and sustainable agricultural practices, in addition to improving the effluent treatment infrastructure, which is essential to minimize the adverse effects of contamination by chemical elements in water bodies.
\end{abstract}

Keywords: aquatic ecosystems, environmental contaminants, forest fragments.

\section{Elevados índices de ferro na água: riscos ambientais para a biota aquática e saúde humana}

\section{RESUMO}

O estudo teve como objetivo avaliar as concentrações de metais nas águas nos Rios Dourados e Brilhante, investigar a influência das características da paisagem no entorno destes rios sobre a qualidade da água e avaliar os riscos associados a contaminação dos metais para a 
biota aquática e saúde humana. As amostragens foram realizadas em dezoitos pontos distribuídos ao longo dos rios em junho de 2016. As concentrações de metais $(\mathrm{Cu}, \mathrm{Zn}, \mathrm{Mn}, \mathrm{Fe}$, $\mathrm{Cr}, \mathrm{Al}$ e Co) na água foram analisadas utilizando espectroscopia de emissão óptica com plasma indutivamente acoplada. Todas as amostras possuíam concentrações de Fe acima do valor limite para a biota aquática $\left(0,3 \mathrm{mg} \mathrm{L}^{-1}\right)$. Além disso, a avaliação do uso e cobertura do solo nas áreas de estudo revelou extensa atividade agrícola, particularmente nas áreas de nascentes do Rio Dourados. A biodisponibilidade de Fe para ambos os rios indicou riscos para a biota aquática e humana. No geral, o elevado teor de Fe nesses rios foi atribuído à atividade antropogênicas nas proximidades desses corpos de água e as características do solo da área. Considerando a importância das bacias hidrográficas, é necessário a implementação das políticas públicas para sua conservação, principalmente as relacionadas ao cultivo de florestas de espécies nativas e práticas agrícolas sustentáveis, além da melhoria da infraestrutura de tratamento de efluentes, que é indispensável para minimização dos efeitos adversos da contaminação por elementos químicos nos corpos hídricos.

Palavras-chave: contaminantes ambientais, ecossistemas aquáticos, fragmentos florestais.

\section{INTRODUCTION}

The exponential expansion of agricultural frontiers and cattle farming in certain regions of Brazil, particularly in Mato Grosso do Sul, have negatively impacted the water quality of these rivers, resulting in significant environmental degradation. Moreover, intensive agriculture and cattle farming around the basins, represented by extensive crops and pastures, have promoted the reduction of riparian forests, leaving the margins of aquatic environments unprotected (Viana et al., 2020). The resultant landscape comprises erosion and silted areas and degradation of the riparian forests, a natural physical barrier for contaminant waste, has caused the flow of contaminants into nearby water bodies (Dos Santos et al., 2020; Riveros et al., 2021).

In this context, the Dourados and Brilhante Rivers are situated in the sub-basin of the Ivinhema River, one of the main tributaries of the Paraná River in southwestern Brazil (Message et al., 2016). Along the Rivers Dourados River (DR) and the River Brilhante (BR), waste generated by agricultural development, contamination of hydrological systems by urban and industrial effluents poses a severe threat to the region. Moreover, the DR watershed comprises a significant portion of the basin that forms part of the city of Dourados and several tributaries of this river pass through the urban perimeter and are further contaminated by anthropogenic activity (Paula et al., 2013; Dalla Costa and Roche, 2020).

Previous studies have demonstrated metal concentrations, particularly Iron $(\mathrm{Fe})$, in the rivers of the Ivinhema River sub-basin exceeding the threshold defined by the National Legislation Conama 357 of 2005 (Souza, 2007; Kottwitz, 2012; Gonçalves, 2013; Dourado et al., 2017; Maceda et al., 2015; Da Rocha et al., 2018; Dalla Costa and Roche, 2020; Dos Santos et al., 2020; Viana et al., 2020). Metal enrichment in aquatic environments, even those considered essential for the maintenance of life, such as Fe, can cause toxicity, representing environmental risks to local biodiversity and compromising human health through the consumption of contaminated water and fish (Sang et al., 2019; Kortei et al., 2020; Yu et al., 2020). Human issues include respiratory problems, severe anemia, gastrointestinal bleeding, cardiovascular collapse, clotting, liver necrosis and progressive organ failure (Maurya et al., 2019; Gashkina et al., 2020).

This study evaluated the metal concentrations in water, mainly $\mathrm{Fe}$, and the landscape composition, including land use and land cover, in the surroundings of the Dourados and Brilhante Rivers to investigate the influence of landscape characteristics on water quality and assess the risks of metals in the water to aquatic biota and human health. 


\section{MATERIAL AND METHODS}

\subsection{Description of the study area}

The DR headwaters are located at the Antônio João municipality, on the border of Mato Grosso do Sul and Paraguay and flow for $370 \mathrm{~km}$ before discharging into the BR. The 344-km long BR headwaters are located in the city of Sidrolândia and run through nine towns situated totally or partially in its basin, namely Angélica, Deodápolis, Douradina, Dourados, Itaporã, Maracaju, Ponta Porã, Brilhante River and Sidrolândia. The DR supplies water to municipalities in the State of Mato Grosso do Sul, including the city of Dourados, which is the second-largest in the state (IBGE, 2014). In addition to residential use, DR water is used for animal and fish farming, irrigation and the industry sectors (Pereira et al., 2007). The BR flows westward and joins the Vacaria and Dourados Rivers to the east, forming the Ivinhema River (Ferreira, 2005). The BR, which receives water from the DR, has several tributaries and is surrounded by areas of extensive agricultural activity, particularly sugarcane production, which is widespread in the State of Mato Grosso do Sul (Rio Brilhante, 2017). The sampling locations were selected according to the vicinity of activities from the headwaters to the river mouth. Sites DR1 and BR1 are located in the headwaters (Figure 1).

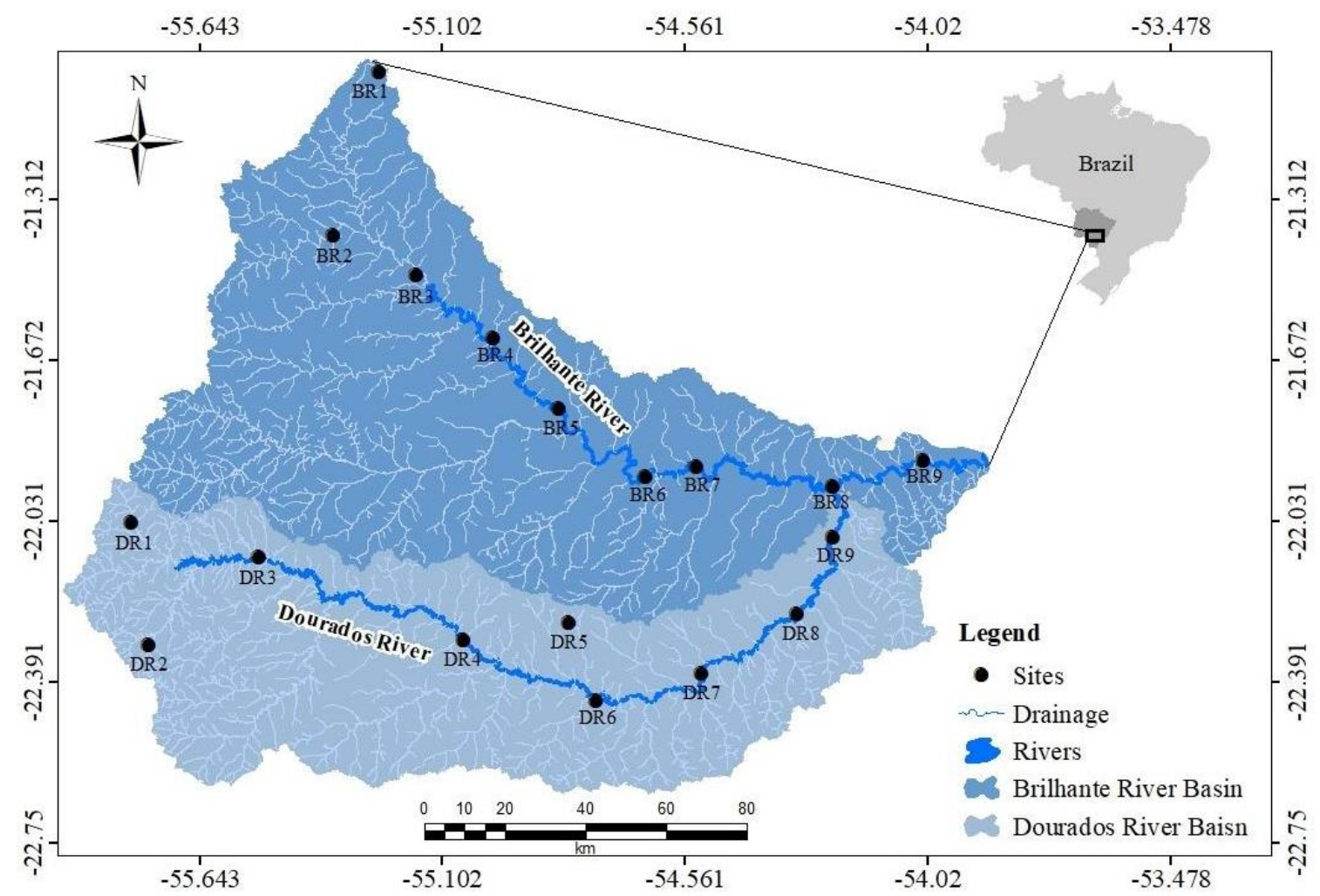

Figure 1. Sampling sites in the Dourados (DR1, DR2, DR3, DR4, DR5, DR6, DR7, DR8 and DR9) and Brilhante (BR1, BR2, BR3, BR4, BR5, BR6, BR7, BR8 and BR9) Rivers, Mato Grosso do Sul, Brazil.

\subsection{Sampling and determination of metals in water}

Water samples were collected at a depth of $20 \mathrm{~cm}$ at eighteen sampling sites along the DR (DR1, DR2, DR3, DR4, DR5, DR6, DR7, DR8 and DR9) and BR (BR1, BR2, BR3, BR4, BR5, BR6, BR7, BR8 and BR9) in June 2016. Water samples were collected in a 1 L sterile amber glass bottle, after collection, water samples were filtered using $0.45 \mu \mathrm{m}$ membrane filter (Millipore Filtration Assembly), acidified at $1 \%$ of the volume for metal preservation (Brandão et al., 2011), transported in refrigerators, and stored at $4{ }^{\circ} \mathrm{C}$ until analysis. The entire procedure 
was performed in triplicate. Analytical blanks were also prepared following the same procedure used for the samples.

The Copper (Cu), Zinc (Zn), Manganese (Mn), Iron (Fe), Chromium (Cr), Aluminum (Al), and Cobalt $(\mathrm{Co})$ concentrations in the water samples were analyzed by Inductively Coupled Plasma Optical Emission Spectrophotometry (ICP-OES) (Thermo Scientific, USA, iCAP $6000 ®$ model) according to the methodology proposed by Mermet and Poussuel (1995). The instrumental parameters of ICP OES were presented in (Table 1).

Table 1. ICP OES instrumental parameters.

\begin{tabular}{lc}
\hline Parameter & Setting \\
\hline RF Power (W) & 1250 \\
Sample flow (L min $\left.{ }^{-1}\right)$ & 0.35 \\
Replicates & 3 \\
Plasma flow rate (L min $\left.{ }^{-1}\right)$ & 12 \\
Integration time (s) & 5 \\
Stabilization time (s) & 20 \\
Nebulization pressure(psi) & 30 \\
Plasma View & Axial \\
Sample Flush Time (s): & 30 \\
Pump Stabilization Time (s): & 5 \\
Nebulizer Gas Flow (L/min): & 0.70 \\
Auxiliary Gas Flow (L/Min): & 0.50 \\
Flush Pump Rate (rpm) & 50 \\
RF Power (W) & 1150 \\
Analysis Pump Rate (rpm) & 50 \\
Coolant Gas Flow (L/Min) & 12 \\
\hline
\end{tabular}

Standard solutions for calibration were prepared by suitable dilution of the stock solutions containing $1000 \mathrm{mg} \mathrm{L}^{-1}$ of $\mathrm{Cu}$ and $\mathrm{Zn}$ and $100 \mathrm{mg} \mathrm{L}^{-1}$ of $\mathrm{Mn}, \mathrm{Fe}, \mathrm{Cr}, \mathrm{Al}$ and Co (Merck and Sigma Aldrich®). Standards at seven different concentrations (including a blank) were prepared (0.005 ppm; $0.01 \mathrm{ppm} ; 0.025 \mathrm{ppm} ; 0.1 \mathrm{ppm} ; 0.5 \mathrm{ppm} ; 1.0 \mathrm{ppm}$ and $2.0 \mathrm{ppm}$ ). The metals selected in this study, wavelengths, correlation coefficients (R2), LOD and LOQ obtained by external calibration are presented in Table 2. The method was validated through the detection limit (LOD) calculated as three times the standard deviation of the blank expressed in concentration divided by slope of the analytical curve, and the limit of quantification (LOQ) was based on ten times the standard deviation of the blank divided by slope of the analytical 
curve according to IUPAC (Long et al., 1983). In addition, the accuracy of the methods was evaluated by addition and recovery tests, conducted in samples of water by spiking $(0.5 \mathrm{mg} / \mathrm{L}$ and $1.0 \mathrm{mg} / \mathrm{L}$ of each analyte) (Table 2).

Table 2. Metals, wavelengths, limits of detection (LOD) and limits of quantification (LOQ), correlation coefficients $\left(R^{2}\right)$ obtained by external calibration and validation of methods using spike concentration samples of water.

\begin{tabular}{ccccccc}
\hline & & & & & \multicolumn{2}{c}{ Spike recovery $(\%)$} \\
\cline { 5 - 7 } Metals & Wavelengths $(\mathbf{n m})$ & LOD $(\mathbf{m g} / \mathbf{L})$ & LOQ $(\mathbf{m g} / \mathbf{L})$ & Linearity $\left(\mathbf{R}^{2}\right)$ & $\mathbf{0 . 5} \mathbf{~ m g} / \mathbf{L}$ & $\mathbf{1 . 0} \mathbf{~ m g} / \mathbf{L}$ \\
\hline $\mathrm{Cu}$ & 327.396 & 0.0013 & 0.0042 & 0.9962 & 111 & 112 \\
$\mathrm{Zn}$ & 213.856 & 0.0004 & 0.0014 & 0.9960 & 92 & 93 \\
$\mathrm{Mn}$ & 257.610 & 0.0002 & 0.0005 & 0.9999 & 112 & 114 \\
$\mathrm{Fe}$ & 239.562 & 0.0011 & 0.0036 & 0.8900 & 91 & 89 \\
$\mathrm{Cr}$ & 283.563 & 0.0011 & 0.0035 & 0.9997 & 110 & 113 \\
$\mathrm{Al}$ & 308.215 & 0.0045 & 0.0151 & 0.9763 & 90 & 93 \\
$\mathrm{Co}$ & 228.616 & 0.0005 & 0.0016 & 0.9999 & 103 & 106 \\
\hline
\end{tabular}

\subsection{Land use and cover}

Land use and land cover ratios at the sampling sites were measured in June 2016 using high-resolution aerial images obtained from Google Earth Pro®, with a pixel size of $1 \mathrm{~m}$. For the study limit, buffers of $2.0 \mathrm{~km}$ were generated around each sampling site (18 sites), and 10 classes of land use and land cover were categorized: an agricultural area, pasture, anthropic occupation, forest fragments, dense forest, planted forest, water bodies, wetlands, fish farming, and exposed soil, according to the Brazilian recommendations (IBGE, 2013). For the interpretation of the images, a visual classification was performed using the scanning tools provided by ArcGIS ${ }^{\circledR} 10.4$ in its test version (ESRI, 2015), and the areas and percentages of each land cover category were calculated.

\subsection{Risk assessment for aquatic biota preservation}

A preliminary risk assessment was conducted for aquatic biota preservation. We calculated the risk quotient (RQ) as the ratio between the individual concentrations of each metal detected in the water samples and their respective Class II freshwater quality standard, provided by Brazilian legislation (Conselho Nacional do Meio Ambiente, 357/2005) (Conama, 2005). The DR and BR waters were classified as Class II, a category that aims to guarantee the preservation of aquatic life. An RQ value $\geq 1$ indicated a possible ecological risk (Godoy et al., 2015). For the risk index (IR) the sum of the RQ values was obtained for each metal individually. Higher IR values indicated a high potential risk of harmful effects to aquatic biota (Evans et al., 2015; Gustavsson et al., 2017). RQ and IR were calculated according to the Equation 1 below: 


$$
R Q=\frac{\text { Water }}{R f D}
$$

Where RQ = risk quotient,

Water: concentrations of each metal detected in the water samples and

$\mathrm{RfD}=$ Reference value for the contaminant of interest $\left(\mathrm{mg} \mathrm{L}^{-1}\right)($ Conama, 2005).

\subsection{Water quality criteria and risk assessment for human consumption}

Risk assessments were used to estimate the probability of a selected factor adversely affecting human health. The water quality criteria (WQC) for human consumption based on health protection were calculated considering the exposure scenario proposed by the World Health Organization (WHO, 2006) for metals.

The reference doses (RfD) were obtained from the U.S. Environmental Protection Agency's Integrated Risk Information System (IRIS) and the Agency for Toxic Substances and Disease Registry (ATSDR). The Water Quality Criteria (WQC) were calculated according to the Equation 2 below:

$$
W Q C=\frac{R f D \times A F x B W}{D W C}
$$

Where RfD is the reference dose for each compound, AF is the allocation factor (10\%), $\mathrm{BW}$ is the body weight of a human $(60 \mathrm{~kg})$ and DWC is the daily water consumption ( $2 \mathrm{~L}$ per day).

\subsection{Literature review about high Fe concentrations found in the study region}

A search was conducted in the following online databases: SciELO, ScienceDirect, Capes periodicals portal and Google Scholar. The keywords used in the search were: water quality, metals, Fe, Ivinhema River Basin and Dourados River Basin. All studies in which the identification of metals in water bodies was performed were considered. The inclusion criteria was selected as: scientific articles that presented $\mathrm{Fe}$ concentration results in water bodies situated in the sub-basin of the Ivinhema River, that is, the Dourados River, Ivinhema River and tributaries of both rivers, were selected.

\section{RESULTS AND DISCUSSION}

\subsection{Metal concentrations in water}

Concentrations of $\mathrm{Cu}, \mathrm{Zn}, \mathrm{Mn}, \mathrm{Fe}, \mathrm{Cr}, \mathrm{Al}$ and $\mathrm{Co}$ were present in both the DR and $\mathrm{BR}$. However, Zn was quantified at only one site in the BR. The Fe concentrations recorded for all the sites exceeded the water threshold values specified by Resolution 357/2005 of the National Environmental Council (Conama, 2005) for Class II freshwater (Table 3).

Site DR1, located in the headwaters, recorded the highest Fe concentrations for the DR sample set, followed by sites DR6, DR7 and DR8 located in the lower portion of the river (Table 3). For the BR analysis, BR6, situated in the lowest portion of the river, displayed higher Fe concentrations than the other BR samples (Table 3). For the remaining metals, only Al at site BR9 showed a value above what is considered safe for aquatic biota by the legislation mentioned above (Table 3). High Fe concentrations were detected in the samples collected from the DR and BR, with values above the limit considered safe for aquatic life according to the Brazilian Legislation Conama (357/2005). Our results were corroborated by previous research conducted on these two rivers, which also indicated high Fe concentrations for the Ivinhema River sub-basin (Figure 2). 
Table 3. Metal concentrations $\left(\mathrm{mg} \mathrm{L}^{-1}\right)$ in the water samples from the Dourados and Brilhante Rivers.

\begin{tabular}{|c|c|c|c|c|c|c|c|c|}
\hline Sites & & $\mathbf{C u}$ & Zn & Mn & $\mathbf{F e}$ & $\mathrm{Cr}$ & Al & Co \\
\hline \multirow{9}{*}{ Dourados River (DR) } & DR1 & $<\mathrm{LOD}$ & $<\mathrm{LOD}$ & $0.0280 \pm 0.0001$ & $3.6838 \pm 0.0003$ & $0.0067 \pm 0.0002$ & $0.0256 \pm 0.0065$ & $<\mathrm{LOD}$ \\
\hline & DR2 & $<\mathrm{LOD}$ & $<\mathrm{LOD}$ & $<\mathrm{LOD}$ & $0.9768 \pm 0.0038$ & $0.0066 \pm 0.0227$ & $0.1035 \pm 0.0004$ & $<\mathrm{LOD}$ \\
\hline & DR3 & $<\mathrm{LOD}$ & $0.0067 \pm 0.3720$ & $0.0160 \pm 0.0001$ & $1.8030 \pm 0.0008$ & $0.0067 \pm 0.0004$ & $<\mathrm{LOD}$ & $<\mathrm{LOD}$ \\
\hline & DR4 & $<\mathrm{LOD}$ & $<\mathrm{LOD}$ & $0.0320 \pm 0.0001$ & $2.4951 \pm 0.0041$ & $0.0068 \pm 0.4938$ & $<\mathrm{LOD}$ & $<\mathrm{LOD}$ \\
\hline & DR5 & $<\mathrm{LOD}$ & $0.0019 \pm 0.6572$ & $0.0397 \pm 0.0004$ & $1.8874 \pm 0.0163$ & $0.0063 \pm 0.0003$ & $0.0376 \pm 0.0064$ & $<\mathrm{LOD}$ \\
\hline & DR6 & $<\mathrm{LOD}$ & $<\mathrm{LOD}$ & $0.0465 \pm 0.0002$ & $2.8249 \pm 0.0055$ & $0.0064 \pm 0.0008$ & $<\mathrm{LOD}$ & $<\mathrm{LOD}$ \\
\hline & DR7 & $<\mathrm{LOD}$ & $<\mathrm{LOD}$ & $0.0488 \pm 0.0005$ & $3.0837 \pm 0.0192$ & $0.0071 \pm 0.0006$ & $<\mathrm{LOD}$ & $<\mathrm{LOD}$ \\
\hline & DR8 & $<\mathrm{LOD}$ & $<\mathrm{LOD}$ & $0.0373 \pm 0.3494$ & $2.6860 \pm 0.0048$ & $0.0065 \pm 0.0004$ & $<\mathrm{LOD}$ & $<\mathrm{LOD}$ \\
\hline & DR9 & $<\mathrm{LOD}$ & $<\mathrm{LOD}$ & $0.0265 \pm 0.0003$ & $2.2479 \pm 0.0199$ & $0.0070 \pm 0.0006$ & $<\mathrm{LOD}$ & $<\mathrm{LOD}$ \\
\hline \multirow{9}{*}{ Brilhante River (BR) } & BR1 & $<\mathrm{LOD}$ & $<\mathrm{LOD}$ & $0.0325 \pm 0.6144$ & $2.0509 \pm 0.0014$ & $0.0075 \pm 0.0006$ & $<\mathrm{LOD}$ & $<\mathrm{LOD}$ \\
\hline & BR2 & $<\mathrm{LOD}$ & $<\mathrm{LOD}$ & $0.0427 \pm 0.0003$ & $2.7166 \pm 0.0092$ & $0.0078 \pm 0.0003$ & $<\mathrm{LOD}$ & $<\mathrm{LOD}$ \\
\hline & BR3 & $<\mathrm{LOD}$ & $<\mathrm{LOD}$ & $0.0383 \pm 0.0002$ & $2.7398 \pm 0.0247$ & $0.0070 \pm 0.0005$ & $<\mathrm{LOD}$ & $<\mathrm{LOD}$ \\
\hline & BR4 & $<\mathrm{LOD}$ & $<\mathrm{LOD}$ & $0.0380 \pm 0.2870$ & $2.7615 \pm 0.0059$ & $0.0073 \pm 0.0005$ & $<\mathrm{LOD}$ & $<\mathrm{LOD}$ \\
\hline & BR5 & $<\mathrm{LOD}$ & $<\mathrm{LOD}$ & $0.0230 \pm 0.0003$ & $2.0902 \pm 0.0051$ & $0.0073 \pm 0.0005$ & $<\mathrm{LOD}$ & $<\mathrm{LOD}$ \\
\hline & BR6 & $<\mathrm{LOD}$ & $0.0019 \pm 0.5190$ & $0.0425 \pm 0.0022$ & $3.0414 \pm 0.0935$ & $0.0068 \pm 0.0004$ & $<\mathrm{LOD}$ & $<\mathrm{LOD}$ \\
\hline & BR7 & $<\mathrm{LOD}$ & $<\mathrm{LOD}$ & $0.0311 \pm 0.3732$ & $2.5054 \pm 0.0181$ & $0.0074 \pm 0.4503$ & $<\mathrm{LOD}$ & $<\mathrm{LOD}$ \\
\hline & BR8 & $<\mathrm{LOD}$ & $<\mathrm{LOD}$ & $0.0356 \pm 0.0013$ & $2.8408 \pm 0.0475$ & $0.0067 \pm 0.0006$ & $0.0642 \pm 0.0039$ & $<\mathrm{LOD}$ \\
\hline & BR9 & $<\mathrm{LOD}$ & $<\mathrm{LOD}$ & $0.0056 \pm 0.0032$ & $1.4280 \pm 0.0475$ & $0.0075 \pm 0.0004$ & $0.4128 \pm 0.0037$ & $<\mathrm{LOD}$ \\
\hline Conama & & 0.009 & 0.18 & 0.1 & 0.3 & 0.05 & 0.1 & 0.05 \\
\hline
\end{tabular}

Maximum permitted value by Brazilian law, in accordance with Resolution 357 (Conama, 2005), for Class II fresh water; <LOD - Analyte concentrations were below the limits of detection. 
Basin Dourados River

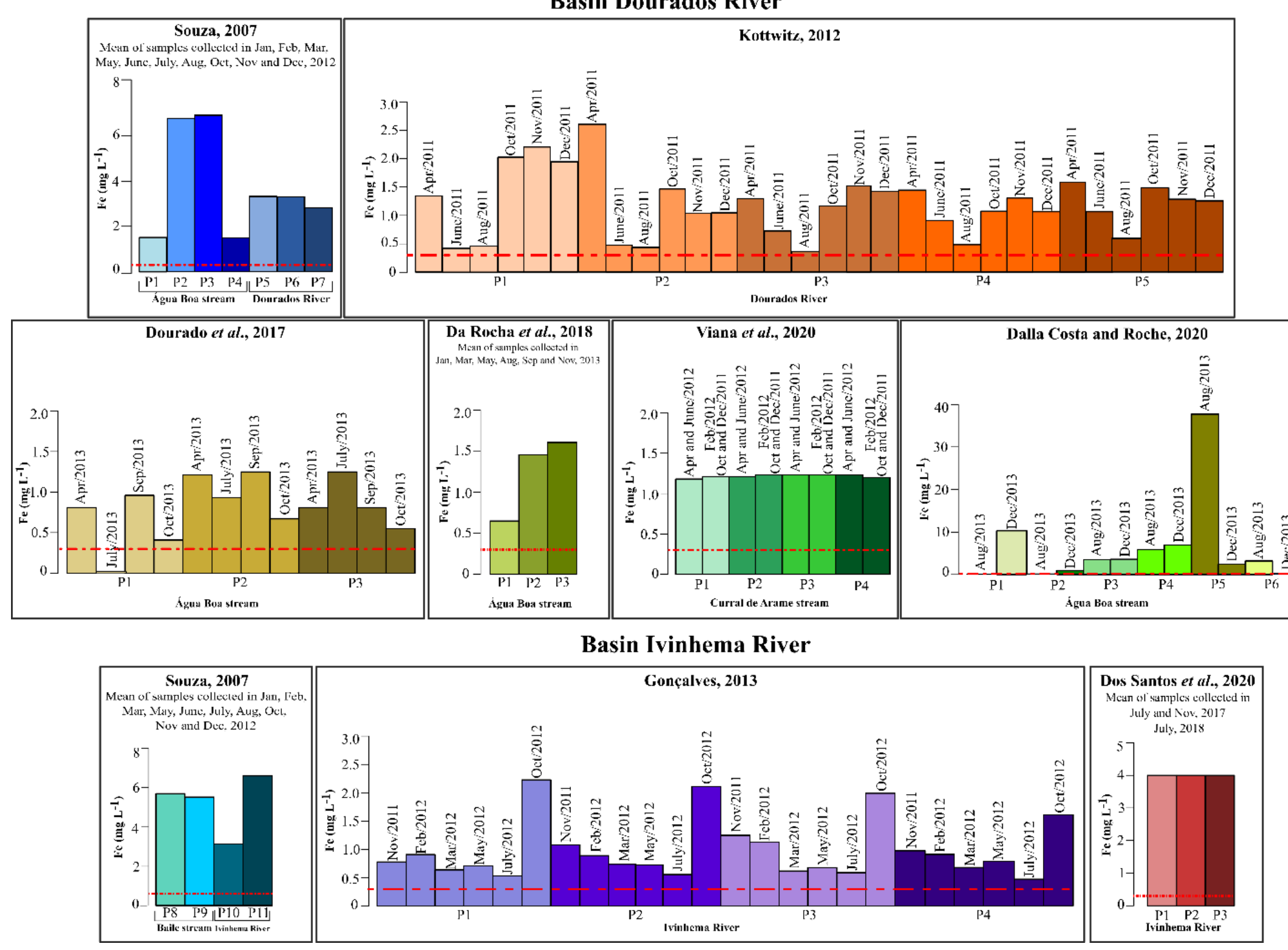

Figure 2. Fe concentrations based on previous studies exceed the limit (red line) specified by the Resolution Conama 357/2005 in rivers of the Ivinhema river sub-basin. 
Excess Fe may be attributed to runoff from agricultural processes such as the application of fertilizers to the soil during land preparation and the spraying of pesticides (Kortei et al., 2020).

Only one of the BR sites, located further downstream, recorded an Al value above the threshold value considered safe for aquatic life according to the Brazilian Legislation Conama (357/2005). This metal is a non-essential element for aquatic life, and high Al concentrations may lead to mutagenic and genotoxic changes and the promotion of bone diseases in vertebrates (Francisco et al., 2018; Rahmani et al., 2018; Chandrapalan and Kwong, 2020). Sources of Al are related to industrial and domestic applications as $\mathrm{Al}$ is typically used in antiperspirants, food preservatives and automobile structures (Callewaert et al., 2014; Gebara et al., 2020).

A comparison of the DR and BR samples with the values established by the Conama $357 / 2005$ legislation revealed a seven-fold $\left(>2.0 \mathrm{mg} \mathrm{L}^{-1}\right)$ increase in the threshold value $(0.3$ $\mathrm{mg} \mathrm{L}^{-1}$ ) for the river water samples (Figure 3).

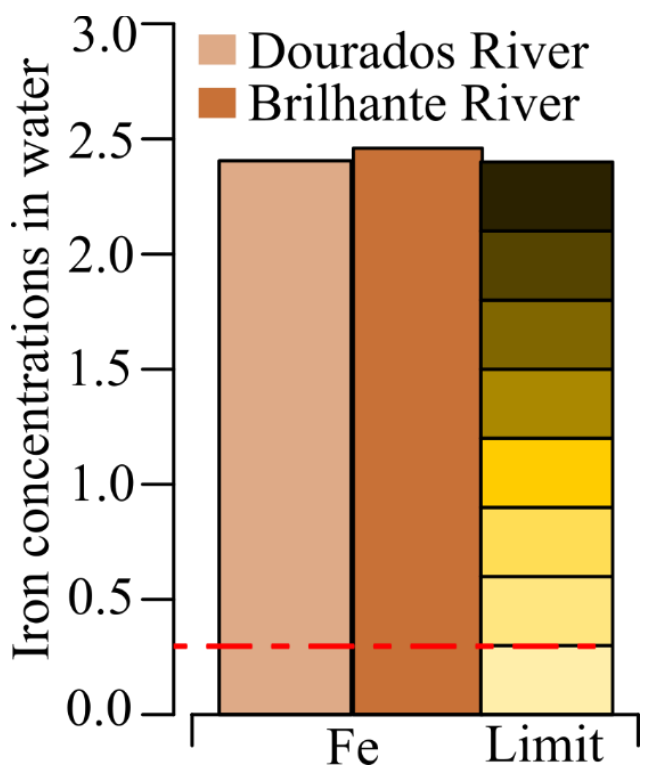

Figure 3. Fe concentrations in the river water samples compared to the limit (red line) specified by the Resolution Conama $357 / 2005$.

The high Fe concentrations detected in the river water pose a severe threat to the aquatic biota of the hydrological systems in the sub-basin and humans reliant on this water for drinking (Bianchi et al., 2019). Fe concentrations in aquatic ecosystems, particularly freshwater systems, have increased significantly in recent years, highlighting a serious environmental concern (Sarkkola et al., 2013; Bjorneras et al., 2017; Chandrapalan and Kwong, 2020).

\subsection{Characterization of land use and land cover}

Agricultural intensity in the vicinity of the samples obtained from the DR decreased consecutively (DR1 > DR2 > DR6 > DR3) (Figure 4). Moreover, the occurrence of forest fragments decreased in the following order: DR4 $>$ DR8 $>$ DR3 $>$ DR5 (Figure 4). The most significant anthropogenic activity occurred in the proximity of DR5 and DR7. DR7 > DR9 > DR8 > DR1 had the most significant pasture areas, while DR9 > DR8 > DR4 > DR7 contained the most significant flood plains. DR2, followed by DR3, were situated in more densely vegetated areas (Figure 4). DR4, followed by DR7 and DR5, contained large areas of exposed soil. Fish farming occurred in the vicinity of DR4 and DR7. Only DR6 presented areas with planted forests. 


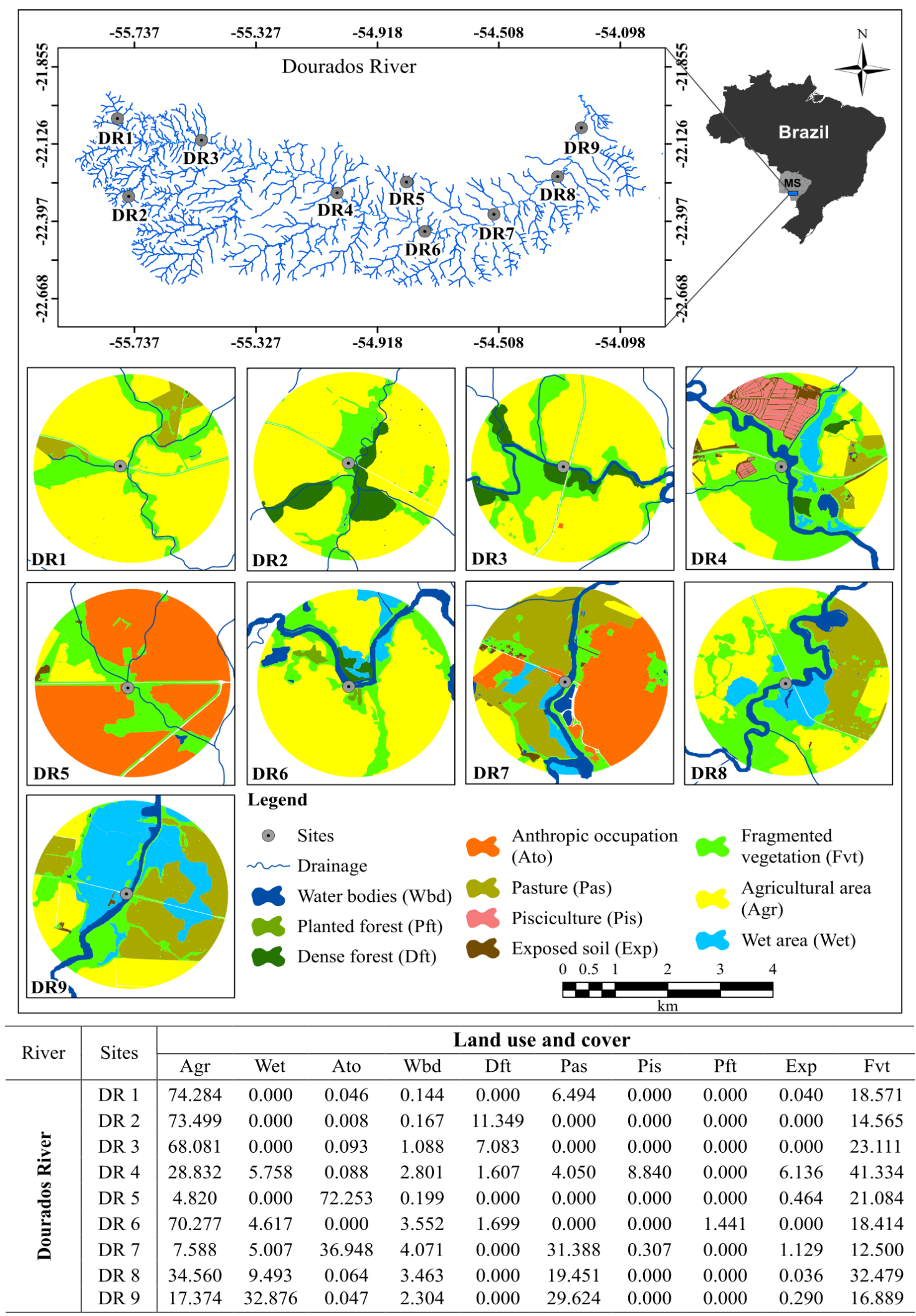

Figure 4. Land use and cover at selected sampling sites along the Dourados River (DR), Mato Grosso do Sul, Brazil.

Agricultural activities were also dominant along the BR and the size of the farming areas adjacent to the sampling sites decreased in the following order: BR1 > BR3>BR4 > BR2 > BR5 > BR6 (Figure 5). BR8 >BR9 > BR2 >BR3 >BR6 > BR5 were the locations with the largest forested areas. Site BR4 was most significantly affected by anthropogenic activity and 
BR2, BR9, and BR4 had the largest adjacent pastures of the sample set (Figure 5). BR4 >BR5 $>\mathrm{BR} 7>\mathrm{BR} 6>\mathrm{BR} 2$ were the sampling sites comprising significant areas of dense vegetation and BR8 > BR9 > BR6 >BR7 were situated in extensive areas of the river (Figure 5). The most significant areas of proposed soil were observed for BR5 $>$ BR8 $>$ BR7 (Figure 5).

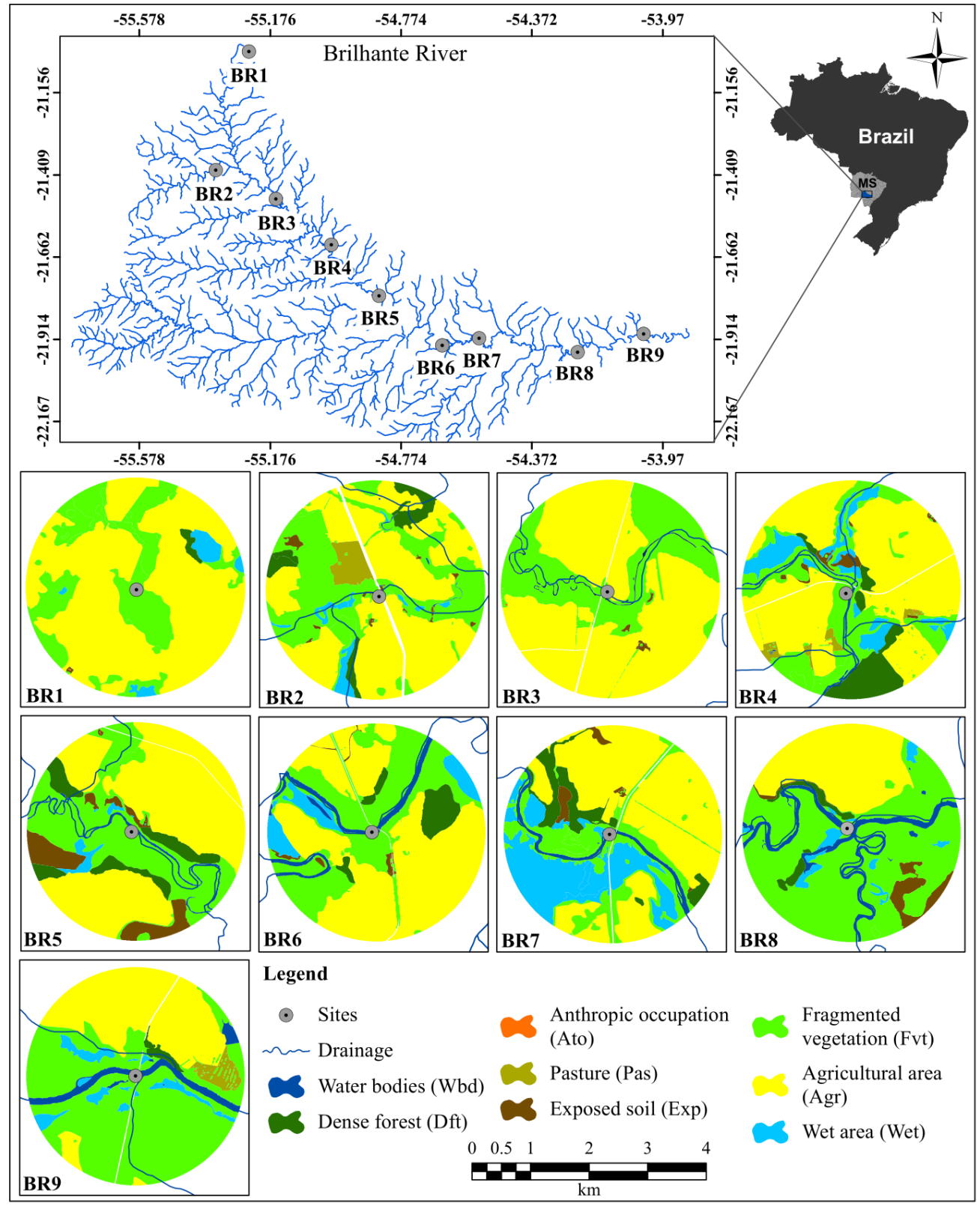

\begin{tabular}{|c|c|c|c|c|c|c|c|c|c|c|c|}
\hline \multirow{2}{*}{ River } & \multirow{2}{*}{ Sites } & \multicolumn{10}{|c|}{ Land use and cover } \\
\hline & & Agr & Wet & Ato & Wbd & $\mathrm{Dft}$ & Pas & Pis & $\mathrm{Pft}$ & Exp & Fvt \\
\hline \multirow{9}{*}{ 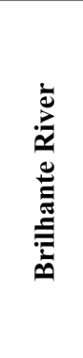 } & BR 1 & 69.902 & 2.752 & 0.007 & 0.000 & 0.735 & 0.000 & 0.000 & 0.000 & 0.065 & 26.539 \\
\hline & BR 2 & 52.459 & 2.616 & 0.005 & 0.162 & 4.871 & 3.551 & 0.000 & 0.000 & 0.953 & 33.690 \\
\hline & BR 3 & 66.887 & 0.000 & 0.012 & 0.941 & 0.000 & 0.000 & 0.000 & 0.000 & 0.351 & 31.019 \\
\hline & BR 4 & 55.764 & 8.808 & 0.038 & 1.277 & 7.820 & 1.655 & 0.000 & 0.000 & 1.414 & 22.597 \\
\hline & BR 5 & 51.602 & 1.454 & 0.006 & 1.749 & 7.038 & 0.000 & 0.000 & 0.000 & 7.415 & 30.394 \\
\hline & BR 6 & 51.229 & 5.977 & 0.001 & 4.152 & 5.214 & 0.000 & 0.000 & 0.000 & 0.847 & 32.212 \\
\hline & BR 7 & 48.562 & 20.961 & 0.004 & 2.641 & 6.800 & 0.000 & 0.000 & 0.000 & 1.595 & 18.748 \\
\hline & BR 8 & 24.227 & 2.886 & 0.000 & 7.005 & 2.232 & 0.000 & 0.000 & 0.000 & 3.782 & 59.869 \\
\hline & BR 9 & 30.913 & 4.442 & 0.016 & 4.852 & 1.037 & 2.437 & 0.000 & 0.000 & 0.000 & 55.669 \\
\hline
\end{tabular}

Figure 5. Land use and cover at selected sampling sites along the Brilhante River (BR), Mato Grosso do Sul, Brazil. 
An evaluation of the average land use and land cover for all the sites along each river revealed more significant agricultural activity along the BR with fragmented vegetation areas, and more significant pasture and fish farming activity along the DR (Figure 6).

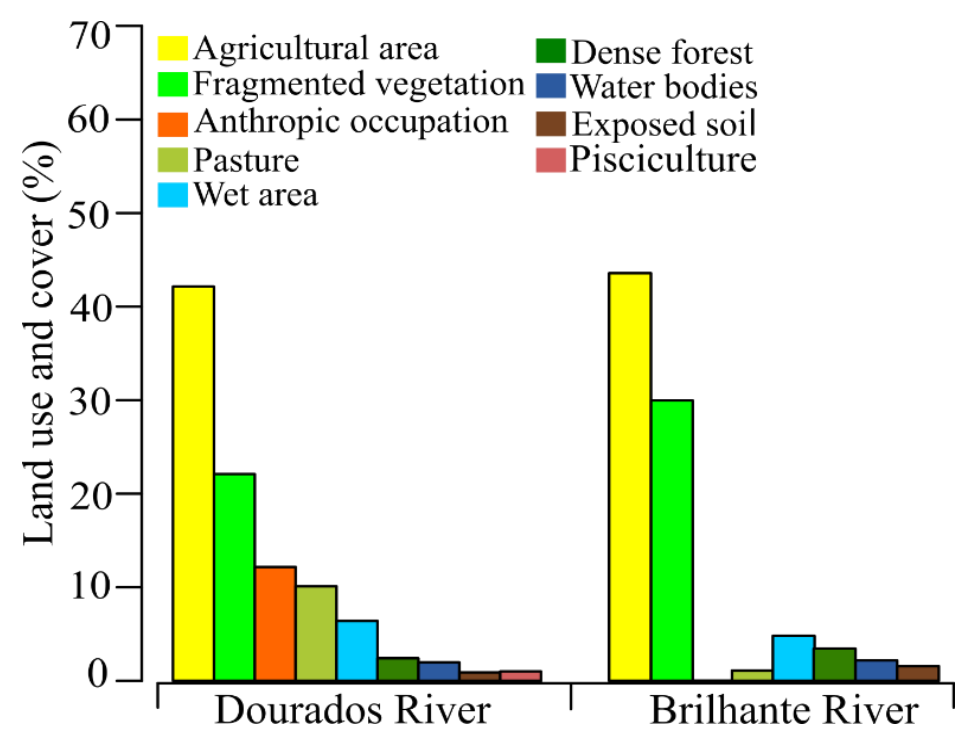

Figure 6. Total percentage of land use and cover in the sampled locations along the Dourados (DR) and Brilhante (BR) Rivers, Mato Grosso do Sul, Brazil.

The land use and coverage data revealed that the DR and BR surroundings are predominantly occupied by agricultural activities, particularly the DR headwater areas. Expansions of agricultural areas combined with deforestation near riverbanks pose severe environmental risks, predominantly related to environmental safety, the integrity of aquatic ecosystems and local biodiversity (Ezemonye et al., 2019). River headwaters directly influence basin hydrology. Moreover, these areas are affected by anthropogenic activity due to their proximity to the watercourse. For this reason, riparian forests are likely to be replaced by agricultural activities, causing vegetation scarcity along the watercourses. Thus, intensive agricultural practices are an essential source of contamination and surface rainwater runoff draining directly into river systems may transport agrochemicals applied to agricultural fields (Bartley et al., 2006).

The forested areas adjacent to both rivers, classified as semi-deciduous seasonal forest, were significantly reduced, further indicating the adverse effects of agriculture on natural vegetation. In Brazil, the Brazilian Forestry Code regulates the protection of indigenous vegetation and defines Permanent Preservation Areas (PPAs) to preserve riverbanks and protect headwaters (Brasil, 2012). Therefore, the reduction in riparian forest areas observed in this study indicated an infringement of the regulations established by the Brazilian Forestry Code. Moreover, numerous areas in the study area comprised fragmented and fragile vegetation remains, possibly indicating the vulnerability of the watercourse to anthropogenic disturbances. In addition, increased agricultural and anthropogenic malpractices result in habitat loss for a significant number of diverse terrestrial animals.

Dystrophic Red Latosol (FDRL) was the dominant soil type for both DR and BR. However, in several stretches of the basins, Dystrophic Red Latosol (DRL) was detected (Figure 7).

Both hydrographic basins were predominantly composed of Dystrophic Red Latosol, which is a type of soil with high levels of Fe oxide (Amaral et al., 2000). Therefore, Fe enrichment in the DR and BR may be related to the dominant soil type in the region in addition to contamination generated by agricultural activity, and urban and industrial effluents in the vicinity of these water bodies (Bonnail et al., 2017; Viana et al., 2020). Viana et al. (2020) 
reported that the combination of soil type in the DR region and the effects of urban waste and agricultural activities lead to a significant increase in Fe levels in aquatic environments. This may be indicative of environmental disturbances, as excess Fe concentrations are toxic to aquatic biota.

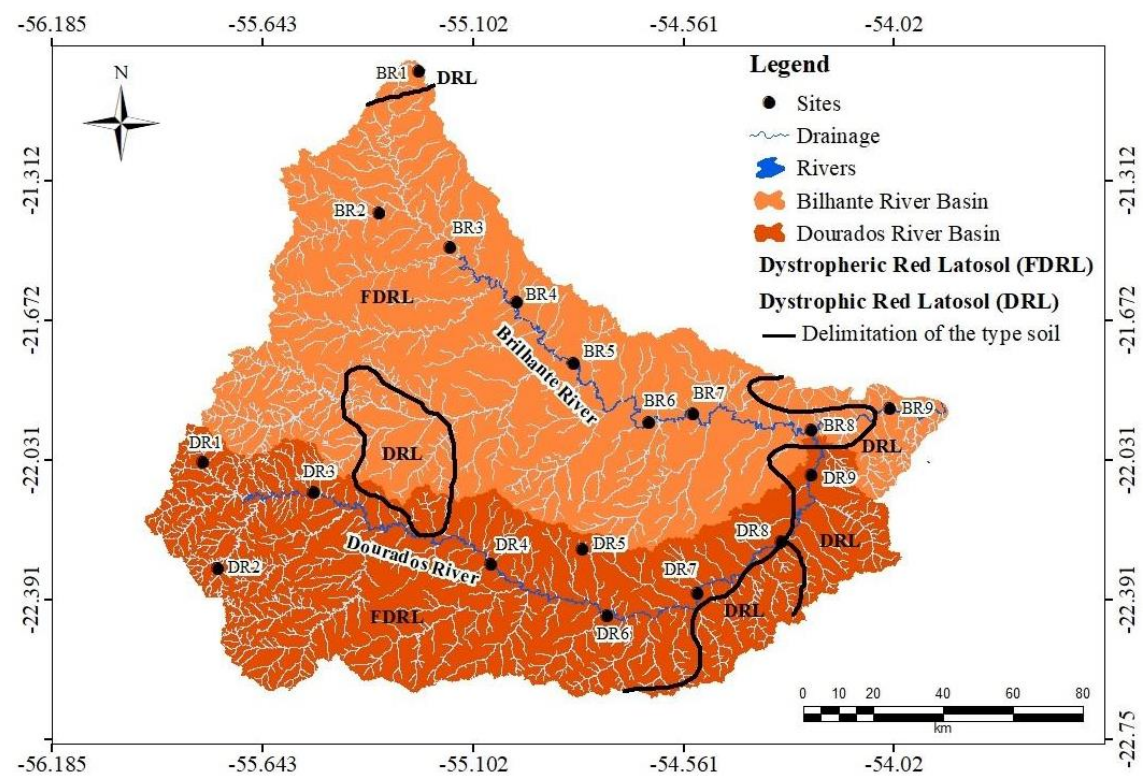

Figure 7. Type of soil surrounding the Dourados (DR) and Brilhante (BR) Rivers, Mato Grosso do Sul, Brazil.

The headwaters for the DR and BR are located at high altitude plateaus exceeding heights of $490 \mathrm{~m}$ and the rivers flow down to minimum depths ranging from 258-371 m (Figure 8).

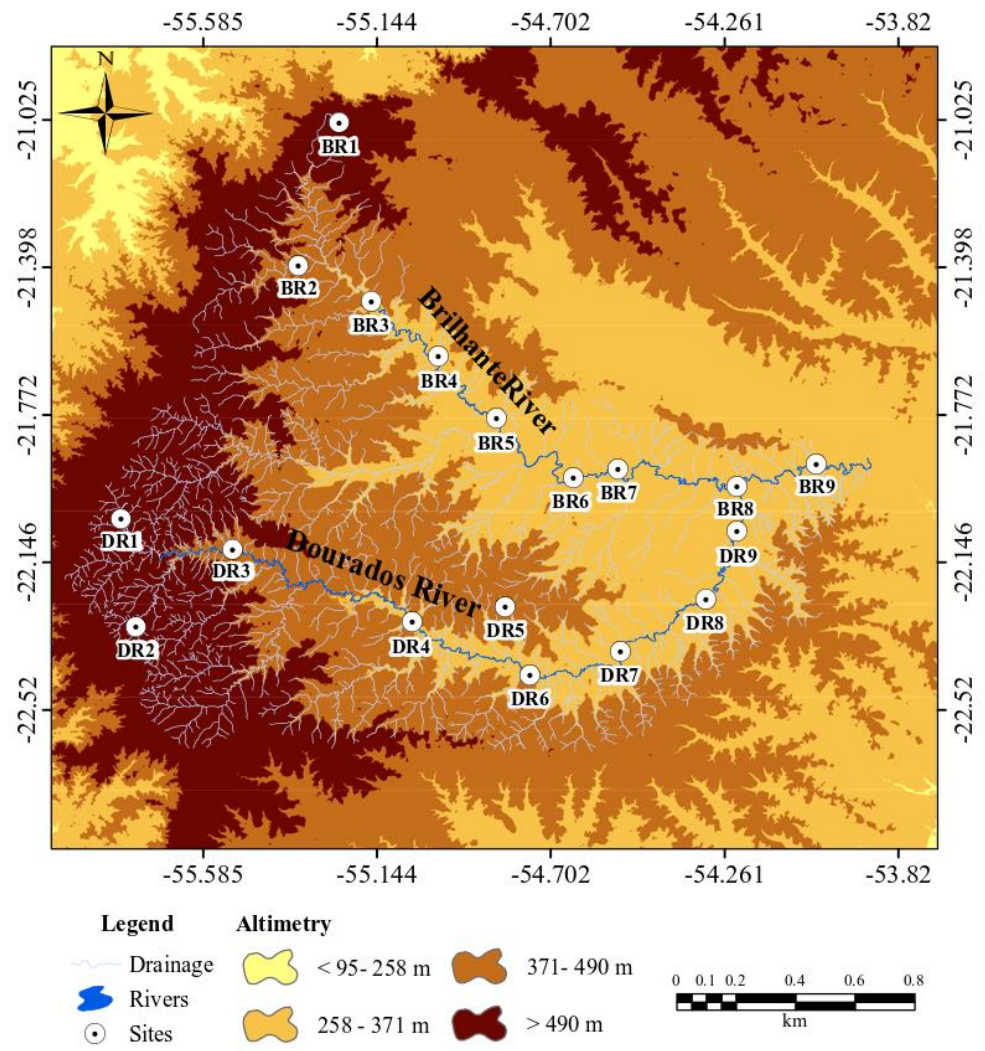

Figure 8. Altimetry of the Dourados (DR) and Brilhante (BR) Rivers, Mato Grosso do Sul, Brazil. 
Another process that may be associated with the release of Fe in the DR and BR is the weathering of rocks, since the headwaters of both rivers are located in rocky areas, and the weathering of Fe-rich rocks releases significant amounts of Fe into the water. Latosols are usually strongly acidic, susceptible to erosion, and represent an advanced stage of weathering as a result of energetic transformations in their composition. Thus, the quality of water can be altered if sediments are carried to water bodies, as a high acidity increases the solubility of several chemical compounds, thus increasing their concentrations in the environment (Embrapa, 2006).

\subsection{Risk assessment for aquatic biota preservation}

The RQ in the rivers indicated that Fe was the metal that exceeded the threshold, posing a health risk for the aquatic biota (Figure 9a). Moreover, an evaluation of the total metal concentration in the samples from both rivers significantly exceeded the threshold value and indicated a risk of metal contamination (Figure 9b).

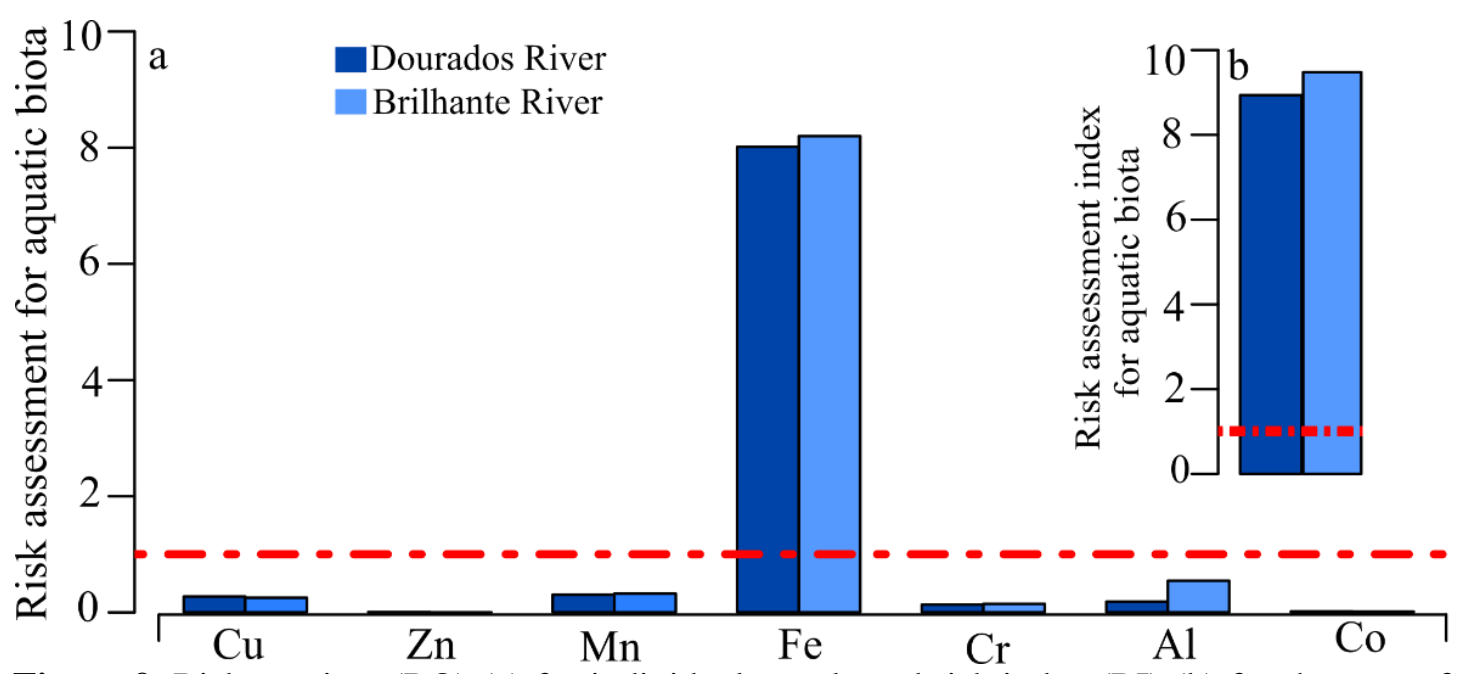

Figure 9. Risk quotient (RQ) (a) for individual metals and risk index (RI) (b) for the sum of individual RQs of average concentrations of metals present in waters in the Dourados and Brilhante Rivers, Mato Grosso do Sul, Brazil. RQ/RI above the red dotted line represents values

$>1$ and, consequently, risk to aquatic biota.

The RI in the DR and BR indicated Fe concentrations $>1$, posing a severe threat to the aquatic biota. These threats include genetic and metabolic diseases and mutagenic and genotoxic impacts. Fe toxicity will most likely adversely affect sensitive aquatic species and favor the selection of more tolerant species (Rahmani et al., 2018; Viana et al., 2020). Assessing the total metal concentration in these rivers revealed a value $>1$, indicating risks for aquatic biota preservation. Therefore, most of the metals analyzed originate from similar sources and may have the same sources and sinks in aquatic environments, thus generating pollutants in water bodies (Bianchi et al., 2019).

\subsection{Water quality criteria for human consumption and risk assessment}

Based on an evaluation of the water quality criterion, Fe was the only metal detected above the threshold value specified for human consumption (Figure $10 \mathrm{a}-\mathrm{b}$ ).

An analysis of the Water Quality Criteria (WQC) indicated the possibility of Fe adversely affecting human health at most of the sampling sites, as the concentrations exceeded the QC threshold value (Umbuzeiro et al., 2010). In addition, Fe concentrations also exceeded the maximum limit indicated by legislation (Conama 357/2005) at all the sampling sites (Table 3 ). Although it is an essential metal for human health, high Fe concentrations are harmful to humans, affecting several physiological processes (Huang et al., 2015). When ingested in 
excess, Fe has been associated with diabetes, cirrhosis, heart alteration, gastrointestinal effects and DNA damage (Gurzau et al., 2003; Jaishankar et al., 2014; Izah et al., 2016; Edokpayi et $a l ., 2018)$. Therefore, this water is not suitable for human consumption.

a)

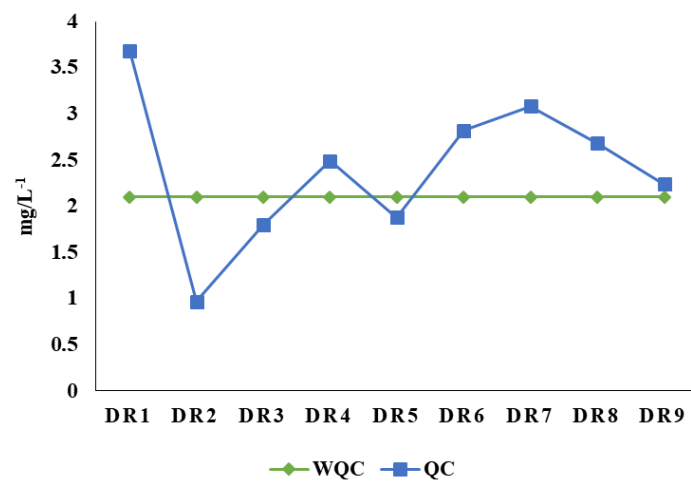

b)

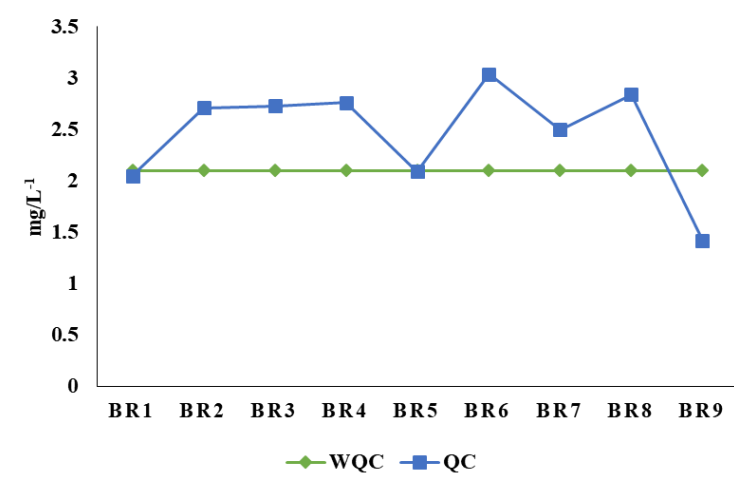

Figure 10. Potential human health risks associated with $\mathrm{Fe}$ contamination detected at the sampling sites along the (a) DR and (b) BR. The green line represents the water quality criterion (WQC), and points plotted above the QC (quantified concentration) represent potential risks for human health.

\section{CONCLUSION}

The decline in quality of the DR and BR waters due to excess Fe can be attributed to the reduction of indigenous forests, intense agriculture adjacent to the watercourse, and soil characteristics in the region. Moreover, sparse and fragile vegetation cover detected in the study area was attributed to agricultural malpractice. Fe concentrations in the DR and BR waters indicated risks for the aquatic biota. Considering the importance of river basins and the local soil structure, the adoption of more rigorous agricultural practices by farmers and the application of stringent conservation policies for indigenous forests are essential. Moreover, improved infrastructure for effluent treatment is required to prevent the contamination of water resources and control local pollution and the risks associated with human health.

\section{ACKNOWLEDGEMENTS}

The authors thank the Federal University of Grande Dourados (UFGD) and the Federal University of Mato Grosso do Sul (UFMS) for the logistical support, the Coordenação de Aperfeiçoamento de Pessoal de Nível Superior (CAPES), the Fundação de Apoio ao Desenvolvimento do Ensino, Ciência e Tecnologia do Estado de Mato Grosso do Sul (FUNDECT), and the Conselho Nacional de Desenvolvimento Científico e Tecnológico (CNPq) for the financial support.

\section{REFERENCES}

AMARAL, J. A. M.; MORCHI, E. P.; OLIVEIRA, H.; CARVALHO FILHO, A.; NAIME, U. J.; SANTOS, R. D. Levantamento semidetalhado dos solos do campo experimental de Dourados, da Embrapa Agropecuária Oeste, Município de Dourados, MS. Rio de Janeiro: Embrapa solos, 2000.

BARTLEY, R.; ROTH, C. H.; LUDWIG, J.; MCJANNET, D.; LIEDLOFF, A.; CORFIELD, J. et al. Runoff and erosion from Australia's tropical semi-arid rangelands: Influence of ground cover for differing space and time scale. Hydrological Processes: An $\begin{array}{lllllll}\text { International Journal, } & \text { v. } 20, \quad \text { n. } 15, \quad \text { p. 3317-3333, } 2006 .\end{array}$ https://dx.doi.org/10.1002/hyp.6334 
BIANCHI, E.; DALZOCHIO, T.; SIMÕES, L. A. R.; RODRIGUES, G. Z. P.; DA SILVA, C. E. M.; GEHLEN, G. et al. Water quality monitoring of the Sinos River Basin, Southern Brazil, using physicochemical and microbiological analysis and biomarkers in laboratoryexposed fish. Ecohydrology \& Hydrobiology, v. 19, n. 3, p. 328-338, 2019. https://doi.org/10.1016/j.ecohyd.2019.05.002

BJORNERAS, C.; WEYHENMEYER, G. A.; EVANS, C. D.; GESSNER, M. O.; GROSSART, H. P.; KANGUR, K. et al. Widespread increases in iron concentration in European and North American freshwaters. Global Biogeochemical Cycles, v. 31, n. 10, p. 1488-1500, 2017. https://doi.org/10.1002/2017GB005749

BONNAIL, E.; BURUAEM, L. M.; MORAIS, L. G.; ABESSA, D. M. S.; SARMIENTO, A. M.; DELVALLS, T. A. Á. Metal contamination and fractionation in sediments from the lower basin of the Vale do Ribeira (SE, Brazil). Environmental Monitoring and Assessment, v. 189, n. 6, p. 245, 2017. https://dx.doi.org/10.1007/s10661-017-5971-x

BRANDÃO, C. J.; COELHO-BOTELHO, M. J.; SATO, M. I.; LAMPARELLI, M. Guia nacional de coleta e preservação de amostras, água, sedimento, comunidades aquáticas e efluentes líquidos. Brasília: ANA, 2011. Available in: http://arquivos.ana.gov.br/institucional/sge/CEDOC/Catalogo/2012/GuiaNacionalDeCol eta.pdf. Access: 24 May 2020.

BRASIL. Presidência da República. Decreto no 12.651, de 25 de maio de 2012. Dispõe sobre a proteção da vegetação nativa; altera as Leis $n^{\circ}$ s 6.938 , de 31 de agosto de 1981, 9.393, de 19 de dezembro de 1996, e 11.428, de 22 de dezembro de 2006; revoga as Leis $\mathrm{n}^{\circ} \mathrm{s} 4.771$, de 15 de setembro de 1965, e 7.754, de 14 de abril de 1989, e a Medida Provisória ${ }^{\circ}$ 2.166-67, de 24 de agosto de 2001; e dá outras providências. Diário Oficial [da] União: seção 1, Brasília, DF, 28 maio 2012.

CALLEWAERT, C.; HUTAPEA, P.; VAN DE WIELE, T.; BOON, N. Deodorants and antiperspirants affect the axillary bacterial community. Archives of Dermatological Research, v. 306, n. 8, p. 701-710, 2014. https://dx.doi.org/10.1007/s00403-014-1487-1

CHANDRAPALAN, T.; KWONG, R. W. Influence of dietary iron exposure on trace metal homeostasis and expression of metal transporters during development in zebrafish. $\begin{array}{llllll}\text { Environmental Pollution, } 2020 . & \text { v. 261, p. }\end{array}$ https://dx.doi.org/10.1016/j.envpol.2020.114159

CONAMA (Brasil). Resolução $\mathrm{n}^{\circ} 357$ de 17 de março de 2005. Dispõe sobre a classificação dos corpos de água e diretrizes ambientais para o seu enquadramento, bem como estabelece as condições e padrões de lançamento de efluentes, e dá outras providências. Diário Oficial [da] União: seção 1, Brasília, DF, n. 053, p. 58-63, 18 mar. 2005.

DA ROCHA, M. P.; DOURADO, P. L. R.; CARDOSO, C. A. L.; CÂNDIDO, L. S.; PEREIRA, J. G.; DE OLIVEIRA, K. M. P. et al. Tools for monitoring aquatic environments to identify anthropic effects. Environmental Monitoring and Assessment, v. 190, n. 2, p. 1-13, 2018. https://dx.doi.org/10.1007/s10661-017-6440-2

DALLA COSTA, B. F.; ROCHE, K. F. Toxicidade aguda em área urbana da microbacia do córrego Água Boa (MS). Engenharia Sanitária e Ambiental, v. 25, n. 1, p. 31-39, 2020. https://dx.doi.org/10.1590/S1413-41522020147956 
DOS SANTOS, S. L.; VIANA, L. F.; MEREY, F. M.; CRISPIM, B. A.; SOLORZANO, J. C.; BARUFATTI, A. et al. Evaluation of the water quality in a conservation unit in CentralWest Brazil: Metals concentrations and genotoxicity in situ. Chemosphere, v. 251, p. 126365, 2020. https://dx.doi.org/10.1016/j.chemosphere.2020.126365

DOURADO, P. L. R.; ROCHA, M. P.; ROVEDA, L. M.; RAPOSO JUNIOR, J. L.; CÂNDIDO, L. S.; CARDOSO, C. A. L. et al. Genotoxic and mutagenic effects of polluted surface water in the midwestern region of Brazil using animal and plant bioassays. Genetics and Molecular Biology, v. 40, n. 1, p. 123-133, 2017. https://dx.doi.org/10.1590/1678-4685-GMB-2015-0223

EDOKPAYI, J. N.; ENITAN, A. M.; MUTILENI, N.; ODIYO, J. O. Evaluation of water quality and human risk assessment due to heavy metals in groundwater around Muledane area of Vhembe District, Limpopo Province, South Africa. Chemistry Central Journal, v. 12, n. 1, p. 1-16, 2018. https://dx.doi.org/10.1186/s13065-017-0369-y

EMBRAPA. Sistema brasileiro de classificação de solos. 2. ed. Rio de Janeiro, 2006.

ESRI. ArcGIS test GIS for the desktop, versão 10.3. West Redlands, 2015.

EVANS, R. M.; SCHOLZE, M.; KORTENKAMP, A. Examining the feasibility of mixture risk assessment: A case study using a tiered approach with data of 67 pesticides from the Joint FAO/WHO Meeting on Pesticide Residues (JMPR). Food and Chemical Toxicology, v. 84, p. 260-269, 2015. https://dx.doi.org/10.1016/j.fct.2015.08.015

EZEMONYE, L. I.; ADEBAYO, P. O.; ENUNEKU, A. A.; TONGO, I.; OGBOMIDA, E. Potential health risk consequences of heavy metal concentrations in surface water, shrimp (Macrobrachium macrobrachion) and fish (Brycinus longipinnis) from Benin River, $\begin{array}{lllllll}\text { Nigeria. Toxicology } & \text { Reports, } & \text { v. } & 6, & \text { p. } & 1-9, & \end{array}$ https://dx.doi.org/10.1016/j.toxrep.2018.11.010

FERREIRA, A. P. Caffeine as an environmental indicator for assessing urban aquatic ecosystems. Cadernos de Saúde Pública, v. 21, n. 6, p. 1884-1892, 2005. https://dx.doi.org/10.1590/S0102-311X2005000600038

FRANCISCO, L. F. V.; CRISPIM, B. D. A.; VIANA, L. F.; NASCIMENTO, H. D. S.; RAPOSO JUNIOR, J. L.; GRISOLIA, A. B. Cytotoxicity, genotoxicity and mutagenicity of Aluminum, Manganese and Lead in Meristematic Cells of Root Allium cepa. Orbital: The Electronic Journal of Chemistry, v. 10, n. 1, p. 60-65, 2018. https://dx.doi.org/10.17807/orbital.v10i1.1037

GASHKINA, N. A.; MOISEENKO, T. I.; KUDRYAVTSEVA, L. P. Fish response of metal bioaccumulation to reduced toxic load on long-term contaminated Lake Imandra. Ecotoxicology and Environmental Safety, v. 191, p. 110205, 2020. https://dx.doi.org/10.1016/j.ecoenv.2020.110205

GEBARA, R. C.; ALHO, L. D. O. G.; ROCHA, G. S.; DA SILVA MANSANO, A.; MELÃO, M. D. G. G. Zinc and aluminum mixtures have synergic effects to the algae Raphidocelis subcapitata at environmental concentrations. Chemosphere, v. 242, p. 125231, 2020. https://dx.doi.org/10.1016/j.chemosphere.2019.125231

GODOY, A. A.; KUMMROW, F.; PAMPLIN, P. A. Z. Ecotoxicological evaluation of propranolol hydrochloride and losartan potassium to Lemna minor L. (1753) individually and in binary mixtures. Ecotoxicology, v. 24, n. 5, p. 1112-1123, 2015. https://dx.doi.org/10.1007/s10646-015-1455-3 
GONÇALVES, P. T. Avaliação espacial e temporal da qualidade da água da sub-bacia do Rio Ivinhema, MS. 2013. Dissertação (Mestrado em Ciência e Tecnologia Ambiental) Universidade Federal da Grande Dourados, Dourados, 2013.

GURZAU, E. S.; NEAGU, C.; GURZAU, A. E. Essential metals-case study on iron. Ecotoxicology and Environmental Safety, v. 56, n. 1, p. 190-200, 2003. https://dx.doi.org/10.1016/S0147-6513(03)00062-9

GUSTAVSSON, M.; KREUGER, J.; BUNDSCHUH, M.; BACKHAUS, T. Pesticide mixtures in the Swedish streams: environmental risks, contributions of individual compounds and consequences of single-substance oriented risk mitigation. Science of the Total $\begin{array}{llllll}\text { Environment, } & \text { v. } & \text { 598, } & \text { p. } & \text { 973-983, }\end{array}$ https://dx.doi.org/10.1016/j.scitotenv.2017.04.122

HUANG, B.; LI, Z.; CHEN, Z.; CHEN, G.; ZHANG, C.; HUANG, J.; NIE, X. et al. Study and health risk assessment of the occurrence of iron and manganese in groundwater at the terminal of the Xiangjiang River. Environmental Science and Pollution Research, v. 22, n. 24, p. 19912-19921, 2015. https://dx.doi.org/10.1007/s11356-015-5230-z

IBGE. Geociências: 2013. http://downloads.ibge.gov.br/downloads_geociencias.htm. Access: 10 Nov. 2020.

IBGE. Censos Demográficos. 2014. Available in: http://www.ibge.gob.br/cidadesat/. Access: 23 Nov. 2020.

IZAH, S. C.; CHAKRABARTY, N.; SRIVASTAV, A. L. A review on heavy metal concentration in potable water sources in Nigeria: Human health effects and mitigating measures. Exposure and Health, v. 8, n. 2, p. 285-304, 2016. https://dx.doi.org/10.1007/s12403-016-0195-9

JAISHANKAR, M.; TSETEN, T.; ANBALAGAN, N.; MATHEW, B. B.; BEEREGOWDA, K. N. Toxicity, mechanism and health effects of some heavy metals. Interdisciplinary Toxicology, v. 7, n. 2, p. 60-72, 2014. https://dx.doi.org/10.2478/intox-2014-0009

KORTEI, N. K.; HEYMANN, M. E.; ESSUMAN, E. K.; KPODO, F. M.; AKONOR, P. T.; LOKPO, S. Y. et al. Health risk assessment and levels of toxic metals in fishes (Oreochromis noliticus and Clarias anguillaris) from Ankobrah and Pra basins: Impact of illegal mining activities on food safety. Toxicology Reports, v. 7, p. 360-369, 2020. https://dx.doi.org/10.1016/j.toxrep.2020.02.011

KOTTWITZ, J. Avaliação espacial e sazonal da qualidade da água do Rio Dourados. 2012. Dissertação (Mestrado em Ciência e Tecnologia Ambiental) - Universidade Federal da Grande Dourados, Dourados, 2012.

LONG, G. L.; WINEFORDNER, J. D. Limit of detection: a closer look at the IUPAC definition. $\begin{array}{llllllll}\text { Analytical Chemistry, } & \text { v. 55, n. 7, p. } 712 \mathrm{~A}-724 \mathrm{~A}, & 1983 .\end{array}$ https://dx.doi.org/10.1021/ac00258a724

MACEDA, E. B.; GRISOLIA, A. B.; VAINI, J. O.; CANDIDO, L. S. Uso de biomarcadores para monitoramento das águas do Córrego Arara no município de Rio Brilhante, MS, Brasil. Revista Ambiente \& Água, v. 10, n. 1, p. 117-129, 2015. https://dx.doi.org/10.4136/ambi-agua.1500 
MAURYA, P. K.; MALIK, D. S.; YADAV, K. K.; KUMAR, A.; KUMAR, S.; KAMYAB, H. Bioaccumulation and potential sources of heavy metal contamination in fish species in River Ganga basin: Possible human health risks evaluation. Toxicology Reports, v. 6, p. 472-481, 2019. https://dx.doi.org/10.1016/j.toxrep.2019.05.012

MERMET, J.; POUSSEL, E. ICP emission spectrometers: 1995 analytical figures of merit. $\begin{array}{llllllll}\text { Applied Spectroscopy, } & \text { v. } 49, \quad \text { n. } 10, & \text { p. }\end{array}$ https://dx.doi.org/10.1366/0003702953965588

MESSAGE, H. J.; SANTOS, D. A.; BAUMGARTNER, M. T.; AFFONSO, I. P. Planícies de inundação: a biodiversidade do rio Paraná ameaçada. Ciência Hoje, v. 334, n. 56, p. 34 39, 2016.

PAULA, S. M.; RAMIRES, I.; DANTAS, F. G. S.; TEODÓSIO, T. K. C.; CAMPOS, K. B. G.; BRABES, K. C. S. et al. Qualidade da Água do Rio Dourados, MS-Parâmetros FísicoQuímicos e Microbiológicos. Evidência, v. 13, n. 2, p. 83-100, 2013.

PEREIRA, S. B.; ALVES SOBRINHO, T.; FEDATTO, E.; PEIXOTO, P. P.; BONACINA, R. Variação temporal do comportamento hidrológico na bacia do Rio Dourados no período de 1973 a 2002. Engenharia Agrícola, v. 27, n. 2, p. 560-568, 2007. https://dx.doi.org/10.1590/S0100-69162007000300027

RAHMANI, J.; FAKHRI, Y.; SHAHSAVANI, A.; BAHMANI, Z.; URBINA, M. A.; CHIRUMBOLO, S. et al. A systematic review and meta-analysis of metal concentrations in canned tuna fish in Iran and human health risk assessment. Food and Chemical Toxicology, v. 118, p. 753-765, 2018. https://dx.doi.org/10.1016/j.fct.2018.06.023

RIO BRILHANTE. Plano Municipal de Saneamento Básico. 2017. Available in: http://riobrilhante.ms.gov.br/wp-content/uploads/2017/12/PMSB-Rio-Brilhante-FINALcompressed.pdf. Access in: 09 December 2020.

RIVEROS, A. F.; SOLÓRZANO, J. C. J.; DE ALMEIDA MONACO, I.; CARDOSO, C. A. L.; SÚAREZ, Y. R.; VIANA, L. F. Toxicogenetic effects on fish species in two subbasins of the upper Paraguay river, Southern Pantanal-Brazil. Chemosphere, v. 264, p. 128383, 2021. https://dx.doi.org/10.1016/j.chemosphere.2020.128383

SANG, C.; ZHENG, Y.; ZHOU, Q.; LI, D.; LIANG, G.; GAO, Y. Effects of water impoundment and water-level manipulation on the bioaccumulation pattern, trophic transfer and health risk of heavy metals in the food web of Three Gorges Reservoir $\begin{array}{llllll}\text { (China). Chemosphere, } 2019 . & \text { v. 232, p. 403-414, }\end{array}$ https://dx.doi.org/10.1016/j.chemosphere.2019.04.216

SARKKOLA, S.; NIEMINEN, M.; KOIVUSALO, H.; LAUREN, A.; KORTELAINEN, P.; MATTSSON, T. et al. Iron concentrations are increasing in surface waters from forested headwater catchments in eastern Finland. Science of the Total Environment, v. 463, p. 683-689, 2013. https://dx.doi.org/10.1016/J.SCITOTENV.2013.06.072

SOUZA, R. A. D. Avaliação de metais em águas na sub-bacia hidrográfica do Rio Ivinhema, Mato Grosso do Sul. 2007. Dissertação (Mestrado em Tecnologia Ambientais) - Universidade Federal do Mato Grosso do Sul, Campo Grande, 2007.

UMBUZEIRO, G. A.; KUMMOROV, F.; REO, F. C. Toxicologia, padrões de qualidade de água e a legislação. INTERFACEHS-Revista de Gestão Integrada em Saúde do Trabalho e Meio Ambiente, v. 5, n. 1, 2010. 
VIANA, L. F.; ROSSO, G. T.; LIMA-JUNIOR, S. E.; SÚAREZ, Y. R.; SOLÓRZANO, J. C. J.; CARDOSO, C. A. L. Avaliação ambiental da qualidade limnológica e de sedimentos em córrego do Centro Oeste do Brasil. Research, Society and Development, v. 9, n. 8, p. e893986288, 2020. https://dx.doi.org/10.33448/rsd-v9i8.6288

WHO. Guidelines for drinking-water quality. 3th ed. Geneva, 2006.

YU, B.; WANG, X.; DONG, K. F.; XIAO, G.; MA, D. Heavy metal concentrations in aquatic organisms (fishes, shrimp and crabs) and health risk assessment in China. Marine $\begin{array}{lllll}\text { Pollution } & \text { Bulletin, } & \text { v. } & 159, & \text { p. }\end{array}$ https://dx.doi.org/10.1016/j.marpolbul.2020.111505 